University of Nebraska - Lincoln

DigitalCommons@University of Nebraska - Lincoln

US Department of Energy Publications

U.S. Department of Energy

2005

\title{
Influence of Sediment Bioreduction and Reoxidation on Uranium Sorption
}

Chongxuan Liu

Pacific Northwest National Laboratory, chongxuan.liu@pnl.gov

John M. Zachara

Pacific Northwest National Laboratory, john.zachara@pnl.gov

Lirong Zhong

Pacific Northwest National Laboratory

Ravi K. Kukkadapu

Pacific Northwest National Laboratory, ravi.kukkadapu@pnl.gov

Jim Szecsody

Pacific Northwest National Laboratory

See next page for additional authors

Follow this and additional works at: https://digitalcommons.unl.edu/usdoepub

Part of the Bioresource and Agricultural Engineering Commons

Liu, Chongxuan; Zachara, John M.; Zhong, Lirong; Kukkadapu, Ravi K.; Szecsody, Jim; and Kennedy, Dave, "Influence of Sediment Bioreduction and Reoxidation on Uranium Sorption" (2005). US Department of Energy Publications. 228.

https://digitalcommons.unl.edu/usdoepub/228

This Article is brought to you for free and open access by the U.S. Department of Energy at DigitalCommons@University of Nebraska - Lincoln. It has been accepted for inclusion in US Department of Energy Publications by an authorized administrator of DigitalCommons@University of Nebraska - Lincoln. 


\section{Authors}

Chongxuan Liu, John M. Zachara, Lirong Zhong, Ravi K. Kukkadapu, Jim Szecsody, and Dave Kennedy 
Influence of Sediment Bioreduction and Reoxidation on Uranium Sorption

CHONGXUAN LIU, * JOHN M. ZACHARA, LIRONG Z H O G, RAVI KUKKADUPA,

J I E. SZECSODY, A N D

DA VE W. KE N N E Y

Pacific Northwest National Laboratory, Richland, Washington 99352

The influence of sediment bioreduction and reoxidation on $\mathrm{U}(\mathrm{VI})$ sorption was studied using $\mathrm{Fe}(\mathrm{III})$ oxide-containing saprolite from the U.S. Department of Energy (DOE) Oak Ridge site. Bioreduced sediments were generated by anoxic incubation with a metal-reducing bacterium, Shewanella putrefaciens strain CN32, supplied with lactate as an electron donor. The reduced sediments were subsequently reoxidized by air contact. $\mathrm{U}(\mathrm{VI})$ sorption was studied in $\mathrm{Na}-$ $\mathrm{NO}_{3}-\mathrm{HCO}_{3}$ electrolytes that were both closed and open to atmosphere and where $\mathrm{pH}, \mathrm{U}(\mathrm{VI})$, and carbonate concentration were varied. Mössbauer spectroscopy and chemical analyses showed that $50 \%$ of the Fe(III)oxides were reduced to $\mathrm{Fe}(\mathrm{II})$ that was sorbed to the sediment during incubation with CN32. However, this reduction and subsequent reoxidation of the sorbed Fe(II) had negligible influence on the rate and extent of $U$ sorption or the extractability of sorbed $\mathrm{U}$ by $0.2 \mathrm{~mol} / \mathrm{L} \mathrm{NaHCO}_{3}$. Various results indicated that $\mathrm{U}(\mathrm{VI})$ surface complexation was the primary process responsible for uranyl sorption by the bioreduced and reoxidized sediments. A two-site, nonelectrostatic surface complexation model best described $\mathrm{U}(\mathrm{VI})$ adsorption under variable $\mathrm{pH}$, carbonate, and $\mathrm{U}(\mathrm{VI})$ conditions. A ferrihydrite-based diffuse double layer model provided a better estimation of $\mathrm{U}(\mathrm{VI})$ adsorption without parameter adjustment than did a goethite-based model, even though a majority of the $\mathrm{Fe}(\mathrm{III})$-oxides in the sediments were goethite. Our results highlight the complexity of the coupled $\mathrm{U}-\mathrm{Fe}$ redox system and show that sorbed $\mathrm{Fe}(\mathrm{II})$ is not a universal reductant for $\mathrm{U}(\mathrm{VI})$ as commonly assumed.

\section{Introduction}

The geochemical behavior of uranium (U), including its reactive transport geochemistry, is a concern in many subsurface environments, especially those influenced by $U$ mining and nuclear materials production $(1,2)$. Various reactions control the subsurface mobility of uranium including U(VI) adsorption to mineral phases; precipitation of U(VI) phosphates, silicates, carbonates, and oxides; U(VI)-U(IV) valence transformations; and the precipitation of highly insoluble U(IV) oxides such as uraninite. Understanding these complex reaction series and their effect on uranium mobility is critical to enabling scientifically credible risk assessments and the development of sound remedial technologies for containment and contaminant abatement.

\footnotetext{
* Corresponding author phone: (509)376-0129; fax: (509)3763650; e-mail: Chongxuan.liu@pnl.gov.
}

$\mathrm{U}(\mathrm{VI})$ is adsorbed to hydroxylated surfaces of $\mathrm{Al}(\mathrm{III}), \mathrm{Fe}-$ (III), and $\mathrm{Si}$ (IV) oxides (e.g., 3, 4-8, 9) and phyllosilicate edges $(10-12)$ and to fixed charge sites on phyllosilicates at intermediate and low $\mathrm{pH}$, and low ionic strength $(10-12)$. Carbonate complexation has a major effect on U(VI) adsorption at and above circumneutral $\mathrm{pH}$ through formation of anionic bis- and tris-carbonate complexes $(6,13,14)$. U(VI) adsorption is often described using equilibrium surface complexation (e.g., 10, 11, 14-17) and ion-exchange models $(10,11)$. Modeling of $U(V I)$ adsorption to natural sediments is complicated because of the multiplicity of mineral adsorption sites and difficulty in their unambiguous identification and characterization. Recent studies have shown that U(VI) adsorption to Fe(III)-oxide containing sediments can be described by an electrostatic model based on a single ferrihydrite component (18-20) or nonelectrostatic surface complexation model with generic site reactions $(14,20,21)$.

Under anoxic conditions, U(VI) can be enzymatically reduced to $\mathrm{U}(\mathrm{IV})$ by metal-reducing bacteria (e.g., 22, 23). This process yields an insoluble precipitate of nanometersized uraninite $\left[\mathrm{U}(\mathrm{IV}) \mathrm{O}_{2}\right]$ that immobilizes $U$ from groundwater. The stimulation of metal-reducing bacteria and the consequent microbial immobilization of contaminant metals including $\mathrm{U}(\mathrm{VI}), \mathrm{Tc}(\mathrm{VII})$, and $\mathrm{Cr}(\mathrm{VI})$ has been proposed as a potential containment technology (www.lbl.gov/NABIR) to scavenge these mobile contaminants from groundwater.

Many metal-reducing bacteria use solid-phase iron (e.g., $24,25)$ and manganese oxides (e.g., 26, 27) as electron acceptors, inducing reductive dissolution and the evolution of $\mathrm{Fe}^{2+}{ }_{\text {(aq) }}$ and $\mathrm{Mn}^{2+}{ }_{\text {(aq) }}$. The bioreduction of $\mathrm{Fe}(\mathrm{III})$ oxides and other $\mathrm{Fe}(\mathrm{III})$-containing minerals generates sorbed $\mathrm{Fe}$ (II) that may function as a reductant for $\mathrm{Cr}(\mathrm{VI})$ (28), $\mathrm{Tc}(\mathrm{VII})$ (29), and possibly U(VI) (30). The natural or stimulated activity of metal-reducing bacteria can alter the distribution and surface chemistry of redox sensitive minerals such as iron oxides in sediments and may change various aspects of uranyl reactive transport chemistry including the nature, rate, and extent of adsorption, precipitation, and redox reactions. Sediment bioreduction may also complicate the U(VI) adsorption process by the redox interactions between $\mathrm{U}(\mathrm{VI})$ and various $\mathrm{Fe}(\mathrm{II})$ forms in the reduced sediments. U(VI) can be reduced by $\mathrm{Fe}(\mathrm{II})$ sorbed on hematite nanoparticles (30) or Fe(II)-containing minerals including nanocrystalline magnetite (31) and pyrite (32). On the other hand, Mn(III)/ (IV) oxides that may persist in sediments in a state of redox disequilibria may oxidize $\mathrm{U}(\mathrm{IV})$ to $\mathrm{U}(\mathrm{VI})(27,33)$ and further complicate the $\mathrm{U}(\mathrm{VI})$ reaction network. The mobility of $\mathrm{U}(\mathrm{VI})$ in natural sediments will be controlled in complex ways by these various competitive processes.

In this study, we investigate the influence of bioreduction and reoxidation on $U$ sorption by a saprolitic sediment that contains Fe(III) and Mn(IV) oxides and a significant phyllosilicate component (vermiculite and illite). The relative importance of $U(V I)$ adsorption to mineral surfaces and its reduction by sorbed biogenic Fe(II) is specifically evaluated. The applicability of several surface complexation models was tested for describing the U(VI) adsorption process that was strong in all of the mineralogically complex sediments studied.

\section{Experimental Section}

Materials. The sediments were obtained from the U.S. DOE Office of Biological and Environmental Research NABIR (Natural and Accelerated Bioremediation Research) Field Research Center (FRC) background site in West Bear Creek 


\section{TABLE 1. FRC Saprolite Sediment Properties ${ }^{a}$}

\section{DCB-extractable $(\mu \mathrm{mol} / \mathrm{g})$ :}

$\begin{array}{lc}\mathrm{Mn} & 35.7 \\ \mathrm{Fe} & 269 \\ \mathrm{Al} & 58.5 \\ \mathrm{AAO}-\text { extracta ble }(\mu \mathrm{mol} / \mathrm{g}) & \\ \mathrm{Mn} & 30.5 \\ \mathrm{Fe} & 41.3 \\ \mathrm{Al} & 34.9 \\ \mathrm{total}(\mu \mathrm{mol} / \mathrm{g})^{c}{ }^{c} & \\ \mathrm{Mn} & 41.7 \\ \mathrm{Fe} & 820 \\ \mathrm{CEC}(\mathrm{meq} / 100 \mathrm{~g}) & 11.6 \\ \text { surface area }\left(\mathrm{m}^{2} / \mathrm{g}\right) & 32.2 \\ \text { oxide Fe(III) } \% \text { ) } & 32 \\ \text { silicate Fe }(\%) & 68 \\ \text { CEC of phyllosilicate } & \\ \text { fraction (meq/100 g) } & \\ \text { dominant mineral components: } & 55.1 \\ \text { quartz, illite, mica, and vermiculite } & \end{array}$

a All data from ref 29 except as noted. ${ }^{b}$ This study. ${ }^{c}$ The total Mn and Fe were determined by X-ray fluorescence. The CEC was determined by ${ }^{22} \mathrm{Na}$ isotopic exchange (57). DCB-extractable Fe was operationally defined as the oxide Fe(III). The difference between the total Fe and DCB-exactable Fe was defined as the silicate Fe.

Valley on the Oak Ridge Site in eastern Tennessee. A nearby $\mathrm{U}(\mathrm{VI})$ plume exists in these same sediment types and pilot experiments are being implemented in field at this location to investigate the microbial immobilization of groundwater $\mathrm{U}(\mathrm{VI})$. The sediments were composited from several distinct strata of a shale-limestone saprolite.

The subsurface materials were air-dried and passed through a 2-mm sieve before use. Surface area was measured by multipoint $\mathrm{N}_{2(\mathrm{~g})}$ adsorption with BET analyses. Extractable oxides were determined using acidic ammonium oxalate (AAO) for poorly crystalline Fe(III) oxides $(34,35)$ and dithionite-citrate-bicarbonate (DCB) treatment for extraction of reducible Fe(III) oxides (36). The mineralogical properties of the sediments have been reported elsewhere (29) and are selectively listed in Table 1.

A dissimilatory metal-reducing bacterium (DMRB), Shewanella putrefaciens strain CN32, was used to reduce the sediments. The cell culturing, harvesting, and washing processes are described elsewhere (37). Briefly, CN32 was routinely cultured aerobically in tryptic soy broth (TSB), harvested from TSB cultures at mid to late log phase by centrifugation, and washed twice with $30 \mathrm{mmol} / \mathrm{L}$ PIPES pH buffer and once with $\mathrm{pH} 7$ bicarbonate buffer to remove residual media. The cells were suspended in bicarbonate buffer $\left(20 \mathrm{mmol} / \mathrm{L} \mathrm{HCO}_{3}\right)$ and purged with $\mathrm{O}_{2}$-free $\mathrm{N}_{2}$ for sediment reduction.

Sediment Reduction and Reoxidation. Bioreduced sediments were generated by incubating $1 \mathrm{~g}$ (dry weight) sediment in $10 \mathrm{~mL}$ of $20 \mathrm{mmol} / \mathrm{L}$ bicarbonate buffer at $\mathrm{pH} 7$ with (7-9) $\times 10^{7}$ cells $/ \mathrm{mL}$ of $S$. putrefaciens $\mathrm{CN} 32,10 \mathrm{mmol} / \mathrm{L}$ sodium lactate as electron donor, and a headspace of $\mathrm{N}_{2}: \mathrm{CO}_{2}(80: 20)$. The incubation was performed at $30^{\circ} \mathrm{C}$ on an orbital shaker (25 rpm). After 60 days of incubation, the sediments in the sealed bottles were pasteurized by heating the bottles in a water bath at $80^{\circ} \mathrm{C}$ for $1 \mathrm{~h}$ and then frozen at $-20^{\circ} \mathrm{C}$ until use. Viable cells of CN32 in the reduced sediments were not detected by growth on TSB agar plates following pasteurization. A recent study showed that all $\mathrm{Mn}$ oxides in the bioreduced FRC saprolite were reduced after 60 days of incubation and the bioreduced FRC sediments were able to reduce $\mathrm{Tc}(\mathrm{VII})$ (29).
Bioreduced-reoxidized sediments were prepared by bubbling air through suspensions of bioreduced sediments for $24 \mathrm{~h}$ in $0.1 \mathrm{mmol} / \mathrm{L} \mathrm{NaHCO}_{3}$ solutions. The reoxidized sediments were collected by centrifugation (5000 rcf for 20 $\mathrm{min}$ ) and air-dried for 7 days at room temperature.

Chemically treated sediments were also prepared to study $\mathrm{U}(\mathrm{VI})$ sorption to the phyllosilicate fraction in the sediments. The chemical treatments were performed under anaerobic conditions in $250 \mathrm{~mL}$ Nalgene centrifuge bottles (Nalge company, Rochester, NY) in which $18 \mathrm{~g}$ (dry weight) of the FRC sediments were reacted with a reductant solution (DCB: $0.1 \mathrm{~mol} / \mathrm{L} \mathrm{NaS}_{2} \mathrm{O}_{4}, 0.3 \mathrm{~mol} / \mathrm{L} \mathrm{Na}$-citrate, and $0.1 \mathrm{~mol} / \mathrm{L}$ $\mathrm{NaHCO}_{3}$ ) for $24 \mathrm{~h}$ on an orbital shaker $(25 \mathrm{rpm})$ at room temperature. After phase separation by centrifugation (5000 rcf for $20 \mathrm{~min}$ ) and removal of supernatants, the treated sediments were reacted with the reductant solution for a second time under the same conditions. The sediments were collected after the second extraction by centrifugation and washed four times with $0.1 \mathrm{mmol} / \mathrm{L} \mathrm{NaHCO}_{3}$ solution to remove residual DCB. No dithionite was detected by UVadsorption spectroscopy at $315 \mathrm{~nm}$ in the fourth washed solution.

Mössbauer Spectroscopy. Sediment samples for Mössbauer spectroscopy were prepared by filtration followed by washing with acetone and drying. The dried sediment (100$200 \mathrm{mg}$ ) was mixed with petroleum jelly and sealed in a $0.5-$ or 2/3-in. thick and 0.5 -in. i.d. $\mathrm{Cu}$ holder. The reduced sediments were handled and stored in an anaerobic chamber. Mössbauer spectra were collected at liquid nitrogen temperature $(77 \mathrm{~K})$ using a $-50 \mathrm{mCi}$ (1.85 GBq) (initial strength) $57 \mathrm{Co} / \mathrm{Rh}$ source. The spectra were folded and evaluated with the Recoil program (University of Ottawa, Canada) using a Voigt-based hyperfine parameter distribution method.

Sorption Kinetics. Time-dependent U(VI) sorption was studied in $0.1 \mathrm{~mol} / \mathrm{L} \mathrm{NaNO}_{3}$ electrolyte with $0.1 \mathrm{mmol} / \mathrm{L}$ $\mathrm{NaHCO}_{3}$ at a solid/solution ratio of $25 \mathrm{~g} / \mathrm{L}$ in an anaerobic chamber (Forma Scientific, Marietta, $\mathrm{OH}$ ) filled with $\mathrm{N}_{2}$ and equipped with a palladium catalytic system for $\mathrm{O}_{2}$ treatment. Dry samples of the sediments were used except for the reduced sediments. Moist, bioreduced sediment was used to avoid mineral changes during drying. The water content of the moist sediments was considered in achieving the desired solid/solution ratio. The sediments and stock solutions of uranyl nitrate, sodium bicarbonate, and electrolyte were added to $125-\mathrm{mL}$ bottles to yield $80 \mathrm{~mL}$ of suspension with the desired uranyl, electrolyte, and bicarbonate concentrations. The suspensions exhibited $\mathrm{pH}$ of 7.0 \pm 0.3 and were equilibrated in a rotating mixer $(10 \mathrm{rpm})$. Suspension aliquots $(1 \mathrm{~mL})$ were collected into $10-\mathrm{mL}$ centrifuge tubes at selected times and centrifuged (5000 rcf for $20 \mathrm{~min}$ ) for phase separation. Pretesting using the pristine sediment spiked with U(VI) indicated that the phase separation scheme provided aqueous samples with composition equivalent to filtration through a $0.1-\mu \mathrm{m}$ filter. The aqueous $\mathrm{U}(\mathrm{VI})$ concentration was analyzed with a Kinetic Phosphorescence Analyzer (KPA) (Chemchek Instrument Inc., Richland, WA). The detection limit of U(VI) with KPA was $4.9 \mathrm{ng} / \mathrm{L}$. All standards and samples were prepared in $0.1 \mathrm{~mol} / \mathrm{L} \mathrm{HNO}_{3}$ to provide a consistent sample matrix (38).

Equilibrium Sorption. Equilibrium sorption was studied as a function of $\mathrm{pH}, \mathrm{U}(\mathrm{VI})$, and carbonate concentrations at a solid/solution ratio of $25 \mathrm{~g} / \mathrm{L}$. Sediments $(0.25 \mathrm{~g}$ dry equivalent) were weighed into 15 -mL Falcon centrifuge tubes and mixed with $\mathrm{NaNO}_{3}(10 \mathrm{~mL})$ to yield final electrolyte concentrations of 0.001 and $0.1 \mathrm{~mol} / \mathrm{L}$. The suspensions were adjusted to desired $\mathrm{pH}$ values with $\mathrm{HNO}_{3}$ or $\mathrm{NaOH}$ before addition of uranyl and $\mathrm{NaHCO}_{3}$ solutions. The tubes were capped during the experiments and the suspensions were 
equilibrated for $48 \mathrm{~h}$ for the pristine, bioreduced, and bioreduced-reoxidized sediments and $120 \mathrm{~h}$ for DCB-treated sediments on the basis of the results of the kinetic sorption experiments. After equilibration on a rotating mixer $(10 \mathrm{rpm})$ in the anaerobic chamber, the suspension tubes were centrifuged (5000 rcf for $20 \mathrm{~min}$ ) and the supernatants were sampled for $\mathrm{pH}$ and $\mathrm{U}(\mathrm{VI})$ measurements. The measured $\mathrm{pH}$ was recorded as the equilibrium $\mathrm{pH}$, and $\mathrm{U}$ sorption was calculated from the difference in $\mathrm{U}_{\mathrm{ToT}}$ and equilibrium $\mathrm{U}(\mathrm{VI})_{(\mathrm{aq})}$ concentration. For selected samples, aqueous and sediment associated $\mathrm{Fe}$ (II) (by $0.5 \mathrm{~mol} / \mathrm{L} \mathrm{HCl}$ extraction) was measured using the Ferrozine method (39). Controls without $\mathrm{U}(\mathrm{VI})$ addition were also performed under the same conditions to measure aqueous and sediment associated Fe(II) as a function of $\mathrm{pH}$. All of the above experiments were equilibrated in a closed system without atmospheric contact. As a comparison, $\mathrm{U}$ sorption to the pristine sediment was also performed under aerobic conditions in equilibrium with atmospheric $\mathrm{CO}_{2}$.

U(VI) Desorption by Carbonate. U(VI) $(26 \mu \mathrm{mol} / \mathrm{L})$ was first sorbed to the sediments using the equilibrium procedures described above in $0.1 \mathrm{~mol} / \mathrm{L} \mathrm{NaNO}_{3}$ and $0.1 \mathrm{mmol} / \mathrm{L}$ $\mathrm{NaHCO}_{3}$ in the anaerobic chamber. The suspension $\mathrm{pH}$ was adjusted to the values that would yield $\mathrm{pH}$ values of 7.0 or 9.5 after equilibrium. After 24 or $168 \mathrm{~h}$ of sorption equilibration, the suspension $\mathrm{pH}$ was measured; these were then spiked with a concentrated $(1 \mathrm{~mol} / \mathrm{L}) \mathrm{NaHCO}_{3}$ solution that was anaerobically prepared to attain a final carbonate concentration of $0.2 \mathrm{~mol} / \mathrm{L}$. The measured $\mathrm{pH}$ values at the end of sorption equilibration were $7.2 \pm 0.2$ and $9.4 \pm 0.2$ in all solutions whose target $\mathrm{pH}$ was either 7.0 and 9.5, respectively. After an additional 1 or $30 \mathrm{~h}$ of equilibration to allow desorption, the suspensions were centrifuged and the $\mathrm{U}(\mathrm{VI})$ in the supernatants was analyzed as described previously.

$\mathrm{U}(\mathrm{VI})$ desorption from the DCB-treated sediments was measured as a function of sorption time in sediment suspensions (25 g/L) containing $0.1 \mathrm{~mol} / \mathrm{L} \mathrm{NaNO}_{3}, 0.1$ $\mathrm{mmol} / \mathrm{L} \mathrm{NaHCO}_{3}$, and $26 \mu \mathrm{mol} / \mathrm{L} \mathrm{U}(\mathrm{VI})$. DCB-treated sediments were further treated by (i) spiking with $\mathrm{FeCl}_{2}$ to yield a final spiked Fe(II) concentration of 0.1 or $1 \mathrm{mmol} / \mathrm{L}$; (ii) 0.5 $\mathrm{mol} / \mathrm{L} \mathrm{HCl}$ extraction for $1 \mathrm{~h}$ to remove Fe(II); or (iii) 0.5 $\mathrm{mol} / \mathrm{L} \mathrm{HCl}$ extraction followed by reoxidation in $0.1 \mathrm{mmol} / \mathrm{L}$ $\mathrm{NaHCO}_{3}$ were also used to investigate the effects of $\mathrm{Fe}$ (II) on uranium sorption and extractability. After variable periods of $U$ sorption, the DCB-treated sediment suspensions were measured for $\mathrm{pH}$ and spiked with $1 \mathrm{~mol} / \mathrm{L} \mathrm{NaHCO}_{3}$ to obtain a final concentration of $0.2 \mathrm{~mol} / \mathrm{L}$. The suspensions were equilibrated for $30 \mathrm{~h}$ for desorption, after which they were centrifuged, sampled, and analyzed as described previously.

Modeling. FITEQL (40) was used to calculate U(VI) aqueous speciation and surface complexation. The aqueous speciation reactions used in the calculations are given in Table S1 in Supporting Information. Both electrostatic and nonelectrostatic surface complexation models were evaluated for their ability to describe $U$ sorption in the pristine, bioreduced, and reoxidized sediments. The models used in this study include those formulated on the basis of ferrihydrite (15) and goethite (16) and a generic two-site model $(18,20)$.

\section{Results and Discussion}

Sediment Properties. The FRC sediments were clay-rich saprolite consisting of sand- and silt-sized aggregates of finer grained materials including quartz, mica, vermiculite, and illite (29). The sediments contained crystalline Fe(III) (hydr)oxides that were extractable by DCB but not by AAO and significant amounts of silicate Fe (68\%) (Table 1). The central doublet near $0 \mathrm{~mm} / \mathrm{s}$ and singlet at $2.5 \mathrm{~mm} / \mathrm{s}$ represent the
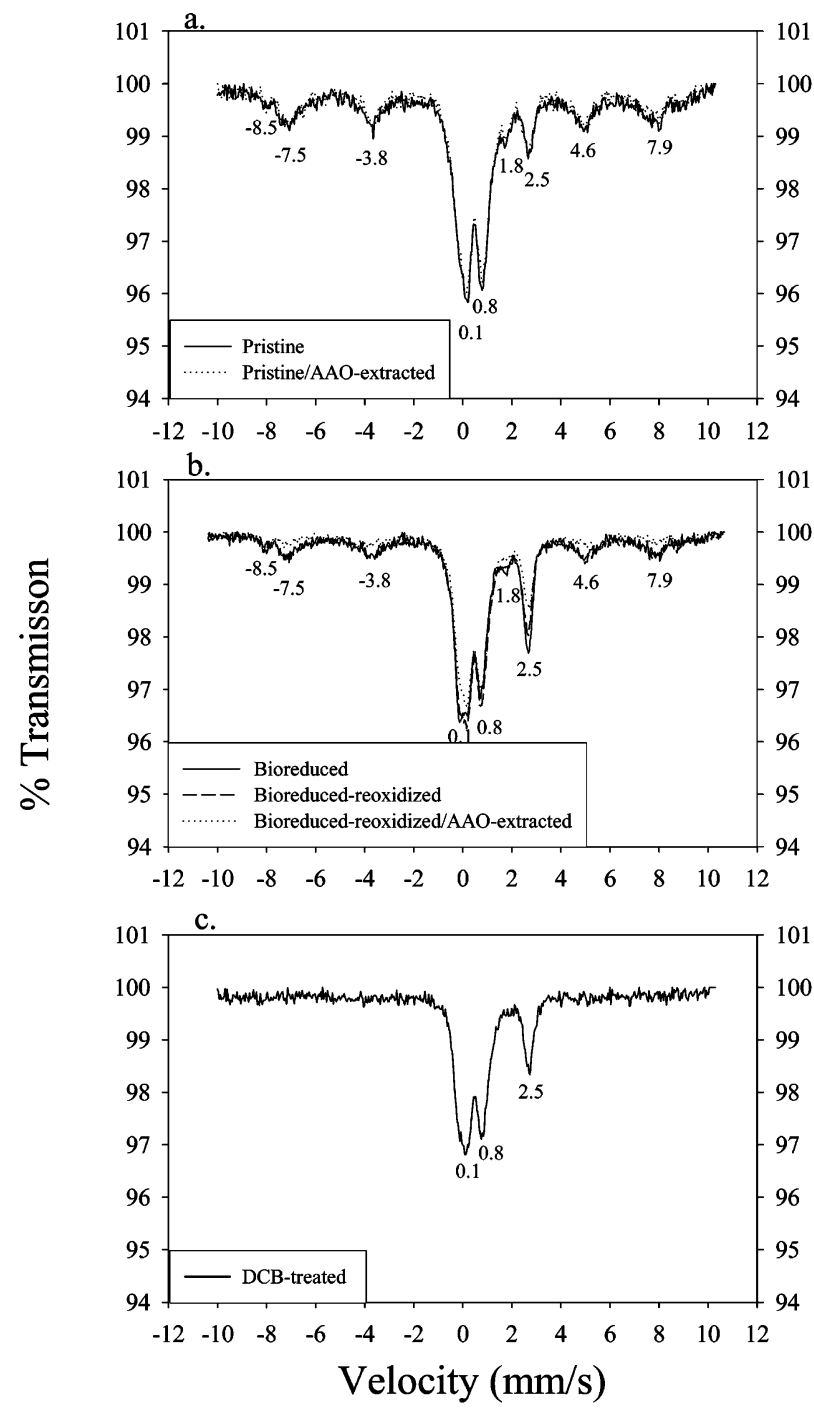

FIGURE 1. Mössbauer spectra of the pristine/AAO-extracted (Figure 1a), bioreduced and bioreduced-reoxidized/AAO-extracted (Figure 1b), and DCB-treated FRC saprolite sediments (Figure 1c). The numbers under spectral peaks denote the peak locations $(\mathrm{mm} / \mathrm{s})$.

Mössbauer spectra of Fe(III) and Fe(II), respectively, in the phyllosilicate fraction of the pristine FRC saprolite (Figure 1a). The peaks at $-7.5,-3.8,1.8,4.6$, and $7.9 \mathrm{~mm} / \mathrm{s}$ corresponded well with five of the six, sextet peaks of small particle size or $\mathrm{Al}$ substituted goethite $(\alpha-\mathrm{FeOOH})(29)$. The peak at $-8.5 \mathrm{~mm} / \mathrm{s}$ indicated the presence of a small amount of hematite. Poorly crystallized iron oxides were negligible in the sediments as indicated by the Mössbauer spectra (Figure 1a) that showed no change with AAO extraction (34, 35). Evaluation of the sediment using transmission electron microscopy (TEM) revealed the abundant presence of goethite aggregates of 100-200 $\mathrm{nm}$ acicular crystallites in the matrix of phyllosilicates (29).

Incubation of the sediment with lactate and CN32 generated $\mathrm{Fe}(\mathrm{II})$ and led to about $50 \%$ reduction in the Mössbauer spectral area of goethite (Figure la and 1b). Silicate $\mathrm{Fe}(\mathrm{III})$ was partially (about $20 \%$ ) reduced to $\mathrm{Fe}$ (II) as indicated by the increased Fe(II) spectral area and the decreased spectral area of the central Fe(III) doublet (Figure 1b). Reoxidation of the bioreduced sediments produced a small decrease in the Fe(II) silicate peak at $2.5 \mathrm{~mm} / \mathrm{s}$ but had little effect on the goethite spectral area (Figure 1b). The extraction of the reoxidized sediments by AAO, however, unexpectedly removed a significant fraction of goethite, as shown by a 


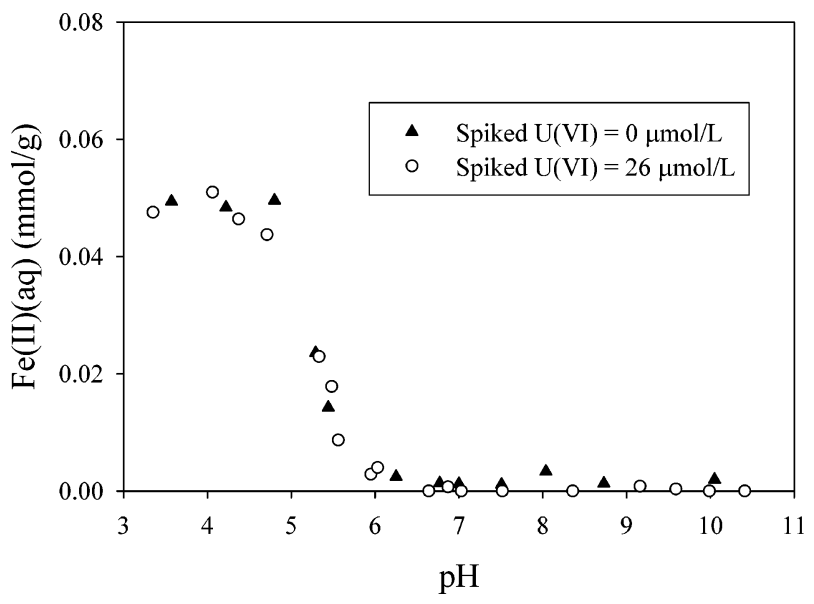

FIGURE 2. Fe(II) desorption from the bioreduced sediment as a function of $\mathrm{pH}$. $\mathrm{Fe}$ (II) desorption was performed in the suspensions of $0.1 \mathrm{~mol} / \mathrm{L} \mathrm{NaNO}, 0.1 \mathrm{mmol} / \mathrm{L}$ carbonate, and spiked $\mathrm{U}(\mathrm{VI})$ of 0 (triangle) or 26 (circle) $\mu \mathrm{mol} / \mathrm{L}$ and was measured after equilibration for $48 \mathrm{~h}$.

reduction in its peak intensity (Figure $1 \mathrm{~b}$ ). The result contrasted with the lack of effect of AAO extraction with the pristine sediments (Figure 1a). This observation may suggest that the goethite structure was weakened by bioreduction or that goethite dissolution during the AAO extraction was promoted by residual $\mathrm{Fe}(\mathrm{II})$ that was somehow resistant to reoxidation (41). The mechanism of this effect is unclear and is currently under continued investigation.

DCB-treatment removed $32 \%$ of Fe from the sediment (Table 1) and eliminated the Mössbauer peaks due to goethite and hematite (Figure 1c). The Fe(III) in the phyllosilicates was partially reduced by DCB treatment as indicated by the spectral area increase of the peak at $2.8 \mathrm{~mm} / \mathrm{s}$ relative to the doublet at $0 \mathrm{~mm} / \mathrm{s}$ (Figure $1 \mathrm{c}$ ).

Microbial reduction produced $0.14 \mathrm{mmol} / \mathrm{g}$ of sedimentassociated Fe(II) that was extractable with $0.5 \mathrm{~mol} / \mathrm{L} \mathrm{HCl}$. A fraction of the biogenic Fe(II) was desorbable below pH 7 in $0.1 \mathrm{~mol} / \mathrm{L} \mathrm{NaNO}_{3}$ and $0.1 \mathrm{mmol} / \mathrm{L} \mathrm{NaHCO}_{3}$ solution (Figure 2 ), and desorption extent increased with decreasing $\mathrm{pH}$. The highest desorbed Fe(II) concentration was $0.05 \mathrm{mmol} / \mathrm{g}$ at $\mathrm{pH}$ 4. Above $\mathrm{pH} \mathrm{7,} \mathrm{all} \mathrm{Fe(II)} \mathrm{was} \mathrm{associated} \mathrm{with} \mathrm{the} \mathrm{solid}$ phase. The Fe(II) desorption profile (Figure 2) was similar to that observed for Fe(II) sorption to goethite (30) and $\mathrm{Cd}^{2+}$ sorption to amphoteric phyllosilicate edge sites (42), suggesting that $\mathrm{Fe}(\mathrm{II})$ existed as a surface complex in the bioreduced sediments. Fe(II) was not detected in the 0.5 $\mathrm{mol} / \mathrm{L} \mathrm{HCl}$ extracts of the pristine and bioreduced-reoxidized sediments.

U(VI) Sorption Kinetics. Uranyl was rapidly sorbed by the pristine and treated sediments (Figure. S1 in Supporting Information). The aqueous U(VI) concentration decreased by over $90 \%$ within the first hour of contact. The kinetic sorption profiles were almost identical for the pristine, bioreduced, and reoxidized sediments. U(VI) was sorbed less to the DCB-treated sediment than to the others. There was little change in aqueous concentration after the initial rapid sorption event.

Both $\mathrm{U}(\mathrm{VI})$ adsorption and reduction with U(IV) precipitation could contribute to the rapid decrease in aqueous $\mathrm{U}(\mathrm{VI})$ concentration (Figure S1). The similar kinetic profiles for sorption in all the sediments regardless of treatment suggested that $\mathrm{U}(\mathrm{VI})$ adsorption, rather than U(IV) precipitation, was the primary sorption reaction. This hypothesis was further tested using desorption experiments.

U(VI) Desorption by Carbonate. Carbonate solutions are often used to extract U(VI) from sediments (e.g., 21, 43, 44-
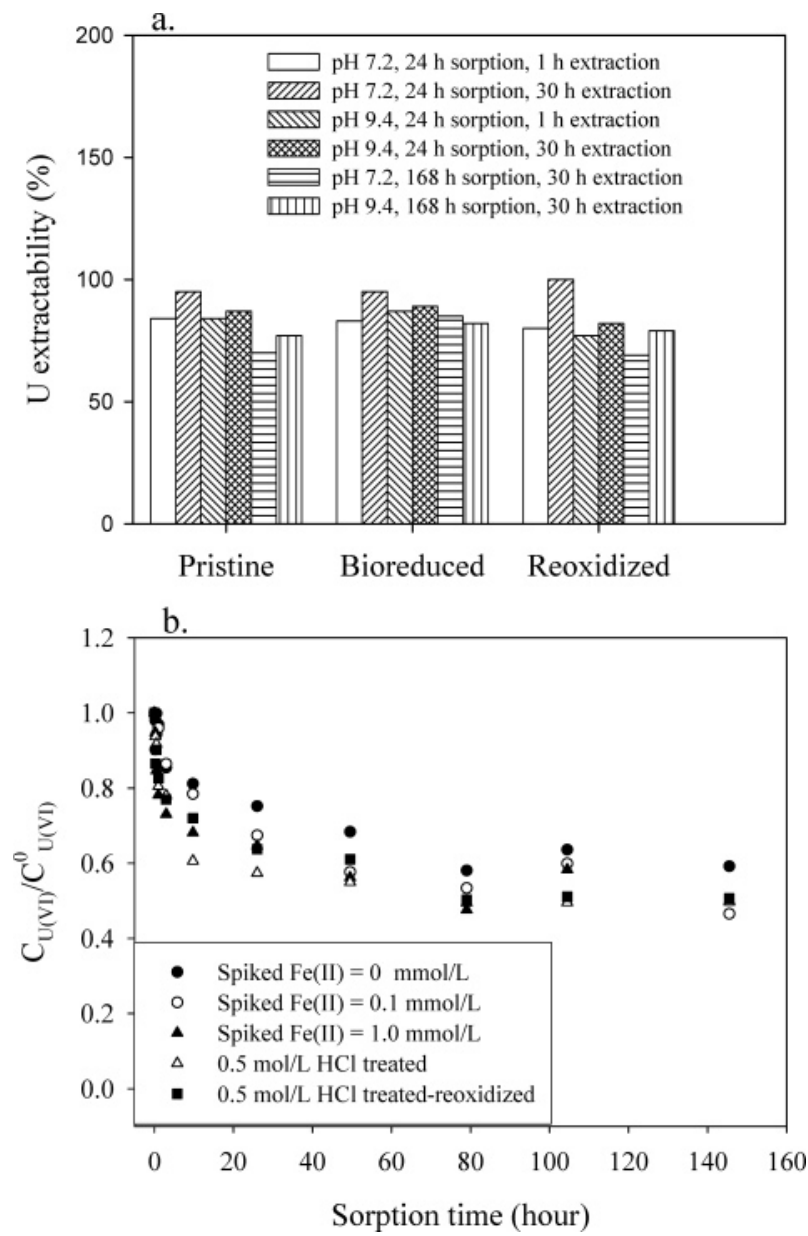

FIGURE 3. U extractability by $0.2 \mathrm{~mol} / \mathrm{L} \mathrm{NaHCO}_{3}$ from sediments with variable equilibration and extraction times. (a) Influence of $\mathrm{pH}$, equilibration time, and carbonate contact duration on $\mathrm{U}$ release from the pristine, bioreduced, and bioreduced-reoxidized sediments and (b) influence of $\mathrm{Fe}$ (II) concentration, $\mathrm{HCl}$ extraction, and reoxidation on $U$ release from DCB-treated FRC sediment [extracted $\mathrm{U}(\mathrm{VI})$ was normalized to total spiked $\mathrm{U}(\mathrm{VI})]$.

46). Concentrated carbonate does not extract inorganic U(IV) phases such as $\mathrm{UO}_{2}$ (uraninite) (47). A $0.2 \mathrm{~mol} / \mathrm{L}$ carbonate solution was used here to evaluate whether reductive precipitation of U(IV) occurred in the bioreduced sediment. Pretests using the pristine sediments showed that the extraction efficiency for U(VI) increased with increasing carbonate concentration and became a constant above 0.1 $\mathrm{mol} / \mathrm{L}$.

The solution of $0.2 \mathrm{~mol} / \mathrm{L} \mathrm{NaHCO}_{3}$ extracted $70-100 \%$ (average $84 \pm 8 \%$ ) of sorbed uranium that resulted from 24 and $168 \mathrm{~h}$ of equilibration (Figure $3 \mathrm{a}$ ). $\mathrm{U}$ extractability from the pristine, bioreduced, and bioreduced-reoxidized sediments was generally the same, suggesting that the sediment redox state had minimal influence on the sorption reaction. The extraction duration and sorption $\mathrm{pH}$ had only minor influence on the extent of $U$ desorption. Desorbed $\mathrm{U}$ increased slightly with extraction time at $\mathrm{pH} 7.2$ and 9.4 and decreased slightly with sorption equilibration time at $\mathrm{pH} 7.2$ in the pristine and bioreduced-reoxidized sediments.

$\mathrm{U}(\mathrm{VI})$ extraction by concentrated aqueous carbonate is an operational measurement of sorbed U(VI) (adsorbed or precipitated) $(21,43-45)$. This approach has been used to quantify the U(VI) reduction by Fe(II) sorbed on the hematite surface (30) (i.e., reduced U(IV) is not extractable). The high extractability of sorbed $U$ in our experiments indicated that it existed primarily as sorbed $U(V I)$. The greatest decrease in 


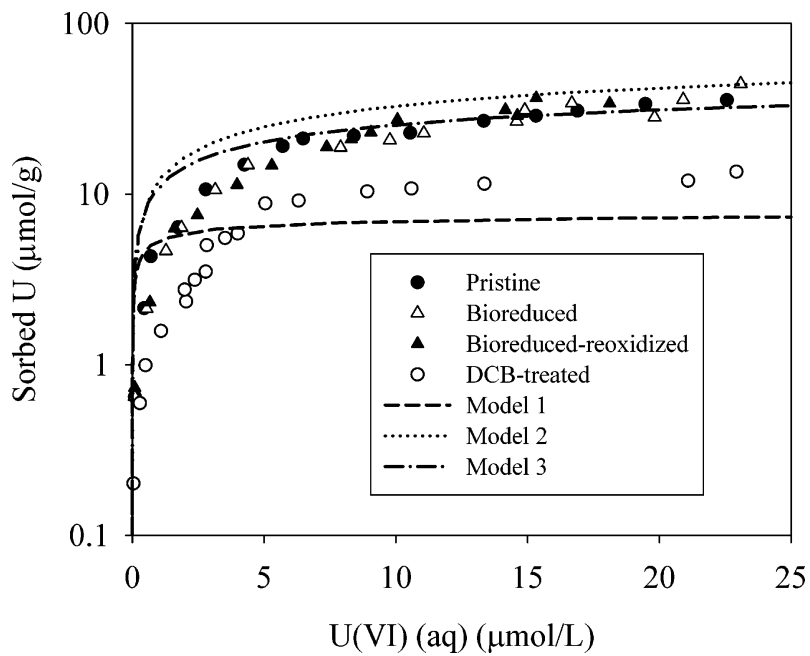

FIGURE 4. $U$ sorption isotherms at $\mathrm{pH}=7.0( \pm 0.2)$ in $0.1 \mathrm{~mol} / \mathrm{L}$ $\mathrm{NaNO}_{3}$ electrolyte with a fixed carbonate concentration of $0.1 \mathrm{mmol} /$ L. The symbols and lines are the experimental and surface complexation modeling results, respectively. Models are given in Table 2.

U extractability with equilibration time was noted in the $30-\mathrm{h}$ carbonate extraction of the DCB-treated sediment (Figure $3 b)$. DCB treatment removes grain coating/cementing Fe(III) and Mn(III/IV) oxides (e.g., Table 1) and enhances the access of $U$ to phyllosilicate edges and interlayers. The similar profiles of $\mathrm{U}(\mathrm{VI})$ extractability from $\mathrm{Fe}(\mathrm{II})$-spiked and Fe(II)-extracted DCB-treated sediments implied that U(VI) adsorption irreversibility rather than reduction caused the decreasing $\mathrm{U}(\mathrm{VI})$ extractability with equilibration time.

U Sorption Isotherms. U sorption at pH $7.0( \pm 0.2)$ increased with increasing $\mathrm{U}(\mathrm{VI})$ concentration in all cases (Figure 4). High affinity type isotherms were observed that displayed surface saturation values ranging from 10 to 40 $\mu \mathrm{mol} / \mathrm{g}$. Sorption extent to the pristine, bioreduced, and bioreduced-reoxidized sediments was virtually identical, indicating that sediment bioreduction and reoxidation had minimal effects on $U$ sorption. In contrast, $U$ sorption to the DCB-treated sediment was lower than all others when total spiked U(VI) was more than $1 \mu \mathrm{mol} / \mathrm{g}$ (or $25 \mu \mathrm{mol} / \mathrm{L}$ ), despite its higher cation exchange capacity (Table 1). U sorption was almost the same in all the sediments when the spiked U(VI) was about $1 \mu \mathrm{mol} / \mathrm{g}$.

Influence of $\mathbf{p H}$, Carbonate Concentration, and Ionic Strength. U sorption showed strong $\mathrm{pH}$ dependence for all the sediments (Figure 5a). U sorption at lower $\mathrm{pH}$ was the same for the pristine sediment regardless of whether the experiment was open or closed to atmospheric $\mathrm{CO}_{2}$. U was strongly sorbed to the sediments above pH 5.5 in closed systems with $0.1 \mathrm{mmol} / \mathrm{L} \mathrm{HCO}_{3}$. In the open system, sorption decreased with increasing $\mathrm{pH}$ above $\mathrm{pH}$ 8. This sorption decrease was due to the increased aqueous uranyl carbonate complexation with increasing $\mathrm{pH}$ in equilibrium with atmosphere $\mathrm{CO}_{2}$. Uranium sorption decreased almost linearly from $\mathrm{pH} 7$ to near zero at $\mathrm{pH} 9$ when the carbonate concentration increased to $10 \mathrm{mmol} / \mathrm{L}$ in the closed system. Above $\mathrm{pH}$ 10, however, sorption increased substantially. Calculations using Minteqa2 (48) and a thermodynamic database compiled from ref 49 indicated that the suspensions were undersaturated with respect to any known uranyl minerals from $\mathrm{pH} 10$ to 11.2. Above $\mathrm{pH} 11.2$, clarkeite $\left(\mathrm{Na}_{2} \mathrm{U}_{2} \mathrm{O}_{7}\right)$ was computed to be saturated.

$\mathrm{U}$ sorption to the bioreduced sediments was not significantly different from the others. U(VI) sorption did not seem to affect the concentration of Fe(II) that was desorbable from the bioreduced sediment (Figure 2) or extractible with 0.5 $\mathrm{mol} / \mathrm{L} \mathrm{HCl}$.
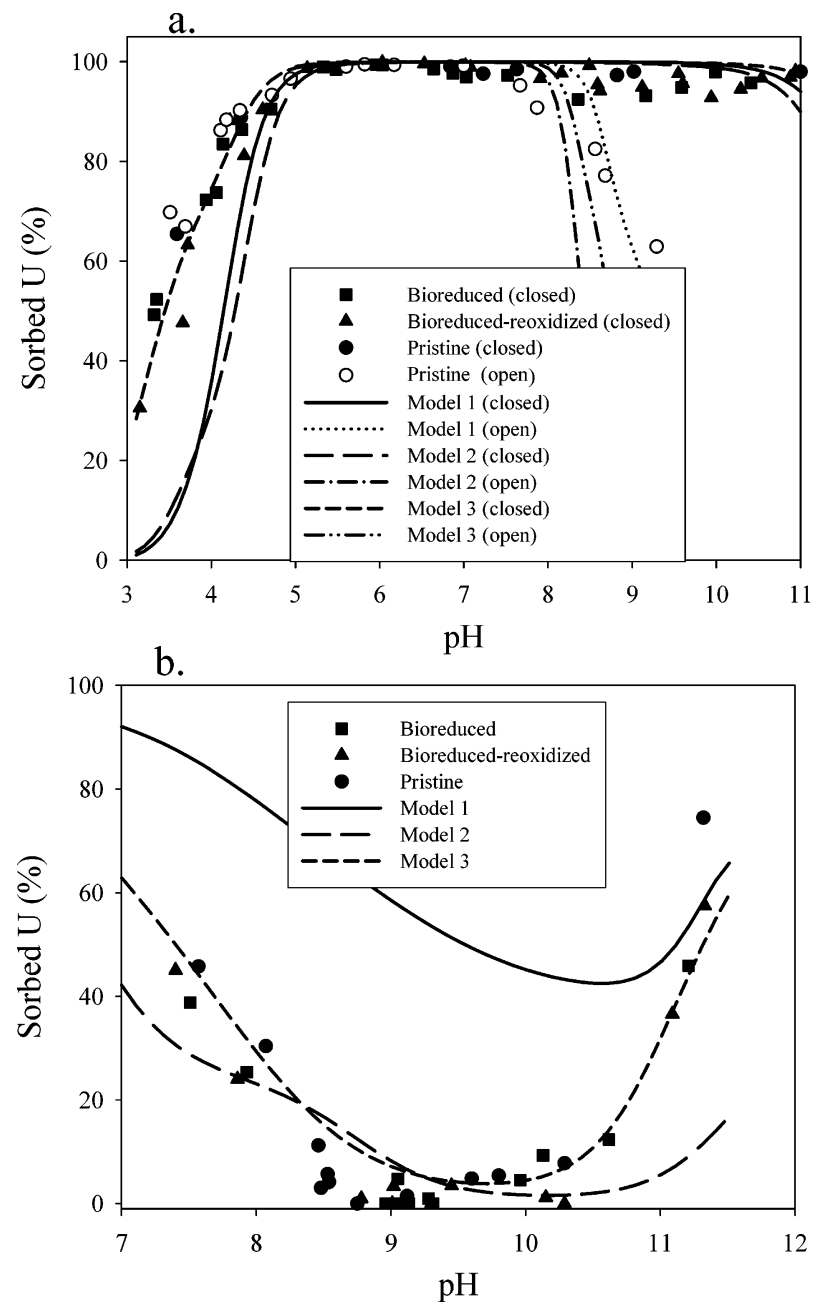

FIGURE 5. U sorption as a function of $\mathrm{pH}$ and carbonate concentration in $0.1 \mathrm{~mol} / \mathrm{L} \mathrm{NaNO}_{3}$. (a) Open (atmospheric $\mathrm{CO}_{2}$ ) and closed $\left(C_{\mathrm{TOT}}=\right.$ $0.1 \mathrm{mmol} / \mathrm{L}$ ) system behavior and (b) closed system behavior at neutral and high pH with $C_{\text {TOT }}=10 \mathrm{mmol} / \mathrm{L}$. Total spiked $\mathrm{U}(\mathrm{VI})=$ $26 \mu \mathrm{mol} / \mathrm{L}$. Symbols and lines are the experimental and modeling results, respectively. Models were given in Table 2.

Thermodynamic calculations at $\mathrm{pH}=7$ for the linked $\mathrm{Fe}(\mathrm{II} / \mathrm{III})$ (aqueous ferrous ion/ferrihydrite) and U(IV/VI) [uraninite/aqueous uranyl dicarbonate] couples reveal that the stable reduced species [e.g., $\mathrm{Fe}^{2+}{ }_{(\mathrm{aq})}$ or $\mathrm{UO}_{2(\mathrm{~s})}$ ] is sensitively dependent on the exact reactant and bicarbonate concentrations and the thermodynamic properties of the solid phases. For this reason, conflicting observations have been recently reported in the literature. For example, Liger et al. (34) reports that sorbed Fe(II) quantitatively reduces U(VI) with a half-life of a few hours through a surface catalytic mechanism. In contrast, other studies $(50-52)$ report a reverse finding that $\mathrm{Fe}(\mathrm{III})$ oxides promote the oxidation of $\mathrm{U}(\mathrm{IV})$ to generate sorbed $\mathrm{Fe}(\mathrm{II})$ as a reaction product. Our results showed that sediment bioreduction had negligible influence on both $U$ sorption (Figures 4, 5, and S1) and carbonate extractability $\left(0.2 \mathrm{~mol} / \mathrm{L} \mathrm{NaHCO}_{3}\right)$ (Figure 3a). These results indicated that $\mathrm{U}(\mathrm{VI})$ reduction by $\mathrm{Fe}(\mathrm{II})$ was either nonexistent or a minor process relative to $U(V I)$ adsorption even though significant sorbed Fe(II) existed in the sediments (Figure 2). The apparent lack of heterogeneous reduction of $\mathrm{U}(\mathrm{VI})$ by sorbed $\mathrm{Fe}(\mathrm{II})$ might result from carbonate complexation which lowers the half-cell potential of the $U(I V)-U(V I)$ couple. It is also possible that the specific surface coordination environments of Fe(II) and U(VI) in the saprolite sediments were not conducive to heterogeneous redox reaction. 


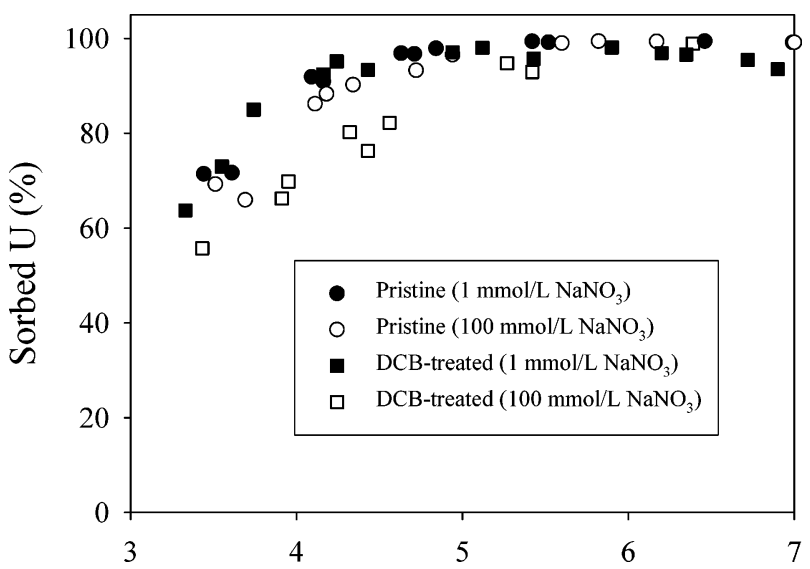

FIGURE 6. Effects of ionic strength on $\mathrm{U}$ sorption to the DCB-treated and pristine sediments in 1 and $100 \mathrm{mmol} / \mathrm{L} \mathrm{NaNO}_{3}$ electrolyte solutions containing $0.1 \mathrm{mmol} / \mathrm{L} \mathrm{NaHCO}_{3}$. Total spiked $\mathrm{U}(\mathrm{VI})=26$ $\mu \mathrm{mol} / \mathrm{L}$.

Uranyl was strongly sorbed by the DCB-treated sediments (Figure 6). U(VI) sorption (at $26 \mu \mathrm{mol} / \mathrm{L}$ ) increased with increasing $\mathrm{pH}$ from $\mathrm{pH} 3.5$ and reached plateau above $\mathrm{pH}$ 5 . The primary sorbents in the DCB-treated sediment were fine-grained phyllosilicates including vermiculite and illite. $\mathrm{U}(\mathrm{VI})$ sorption to the DCB-treated sediment was lower than the pristine sediment when the $\mathrm{pH}$ was below 5 (at 100 $\mathrm{mmol} / \mathrm{LNaNO}_{3}$ ) (Figure 6) but was comparable to the pristine sediment above this $\mathrm{pH}$. At higher concentration, $\mathrm{U}(\mathrm{VI})$ sorption to the DCB-treated sediment was lower than the others at pH 7 (Figure 4). Decreasing the electrolyte concentration increased $U$ sorption at low $\mathrm{pH}$ on the DCB-treated sediment, suggesting the presence of uranyl ion exchange on phyllosilicate fixed charge sites (10-12). In contrast, electrolyte concentration change had minimal effect on U(VI) sorption to the pristine sediments, indicating that U(VI) ion exchange was negligible when iron oxides were present.

The similarity of U(VI) sorption to the pristine, bioreduced, and bioreduced-reoxidized sediments suggested that phyllosilicates were an important U(VI) sorbent in the FRC sediment. Moreover, the equivalent sorption properties of the pristine and bioreduced sediments implied a minimal role for $\mathrm{Mn}$ (III/IV) oxides as these were completely removed from the bioreduced sediment. However, the decreased U(VI) sorption observed in the DCB-treated sediments under certain conditions indicated that partial Fe(III) dissolution of goethite aggregates during bioreduction is unlikely to have appreciably influenced goethite surface site concentrations.

Modeling of U(VI) Sorption. Two approaches have been used to model $\mathrm{U}(\mathrm{VI})$ adsorption to sediments, including the component additivity (CA) and the generalized composite (GC) approaches $(18,20)$. The CA approach incorporates surface reactions for individual minerals or sorbent phases (often developed on model mineral phases) that are summed to describe surface complexation behavior of the mineral assemblage. Limited studies have found that U(VI) adsorption to Fe(III)-oxide containing sediments may be described by $\mathrm{U}(\mathrm{VI})$ adsorption to only the iron oxide component (18-20). The GC approach describes the adsorptive reactivity of sediments using "generic" surface complexation reactions with the stoichiometry and formation constants determined by fitting experimental data.

In this study, we tested three modeling approaches to describe equilibrium $\mathrm{U}(\mathrm{VI})$ sorption as a function of $\mathrm{pH}$ and carbonate and $U$ concentration. A surface complexation approach was taken because the experimental data implied that sorption resulted from an adsorption reaction. Model 1 was formulated with goethite as the sorbent because it was the dominant Fe(III)-oxide in the sediments (Figure 1). This model was a one-site, electrostatic triple layer model (Table 2 ). The surface reactions and their constants were taken from Villalobos et al. (16). The total surface site concentration was calculated using a goethite surface site density of $0.066 \mathrm{~mol}$ sites/mol Fe (16) and the DCB-extractable Fe(III) oxide content in mol Fe(III)/g of sediment (Table 1). Model 2 was a two-site diffuse layer model based on U(VI) adsorption to ferrihydrite with surface reactions and reaction constants from Waite et al. $(15,20)$ and Davis $(20)$. The total surface site concentration was calculated by assuming that all of DCB-extractable iron oxides were ferrihydrite with a site density of 0.875 sites $/ \mathrm{mol}$ Fe. The strong complexation sites were assumed to represent $0.21 \%$ of the total (15). Model 3 allows $\mathrm{U}(\mathrm{VI})$ surface complexation to two generic sorption sites without involving other competitive surface reactions. We used the sorption results at high and low carbonate concentration (Figure 5) to parametrize reaction constants for model 3 that were then applied to the sorption isotherms in Figure 4 for validation. Minor desorption irreversibility and potential reduction of $\mathrm{U}(\mathrm{VI})$ in the bioreduced sediments were neglected, that is, all the sorption data in Figures 4 and 5 were used to either estimate the parameters or validate the model. The total surface site concentration for model 3 was calculated using a generic site density of $3.84 \mu \mathrm{mol} / \mathrm{m}^{2}$ as suggested by Davis and Kent (53) and a specific surface area for the sediment (Table 1). The aqueous species and reactions in Table $\mathrm{S} 1$ were included in all of the models. Aqueous species $\mathrm{Ca}_{2} \mathrm{UO}_{2}\left(\mathrm{CO}_{3}\right)_{3}$ was not included in the modeling because of its questionable formation constant (49) and minor effect on $\mathrm{U}(\mathrm{VI})$ adsorption in our systems (Figure S2 in Supporting Information). U sorption to the DCB-treated sediment was not modeled because it required independent characterization of ion-exchange reactions to simulate the effects of ionic strength at lower pH (Figure 6). Furthermore, the global removal of all iron oxides through bioreduction is probably not a realistic scenario.

Both models 1 and 2 reasonably well predicted $U$ adsorption above $\mathrm{pH} 4.7 \mathrm{in}$ systems with $0.1 \mathrm{mmol} / \mathrm{L} \mathrm{NaHCO}_{3}$ without parameter adjustment (Figure 5a). The ferrihydrite model provided better predictions of U(VI) adsorption than did the goethite model at high carbonate concentration (Figure 5b) although goethite was the major Fe(III) oxide in the sediment. This observation was consistent with a previous study where U(VI) adsorption to a Hanford sediment was well described by a ferrihydrite-based model even though the primary Fe(III) oxide was hematite (19). The experimental results were well described by a GC model (model 3, Figure 5) with reaction constants listed in Table 2. The model was parametrized in two steps. First, the high affinity site concentration and reaction constants for the $\left(\mathrm{SO}_{2}\right) \mathrm{UO}_{2}$ complex on both the strong and weak sites were fit to the adsorption data below pH 6 in Figure 5a. Then, the model was used to fit the $U$ adsorption data at high carbonate concentration (Figure 5b) by adjusting the reaction constants of the ternary uranyl carbonate surface species, $\left(\mathrm{SO}_{2}\right) \mathrm{UO}_{2} \mathrm{CO}_{3}{ }^{2-}$, on both the strong and weak surface sites.

Both models 2 and 3 provided good predictions of the adsorption isotherms (Figure 4). The goethite model underpredicted the isotherm by a factor of $1.5-8$. These results seem to support the GC approach $(18,20)$ for modeling $U$ adsorption to sediments with complex mineralogy. All three models predicted the observed increase in $\mathrm{U}(\mathrm{VI})$ adsorption above pH 10.5 with $10 \mathrm{mmol} / \mathrm{L} \mathrm{NaHCO}_{3}$ (Figure 5b). The computed adsorption increase resulted from surface site deprotonation that led to the increased sorption of $\mathrm{U}(\mathrm{VI})$ as the $\left(\mathrm{SO}_{2}\right) \mathrm{UO}_{2}$ surface complex. The precipitation of clarkeite $\left(\mathrm{Na}_{2} \mathrm{U}_{2} \mathrm{O}_{7}\right)$ may have occurred at the highest $\mathrm{pH}$ values (e.g., $>\mathrm{pH}=11.2$ ) as the aqueous solution was supersaturated with this phase. 


\section{TABLE 2. Surface Complexation Models for U(VI) Adsorption}

\section{surface reactions}

model $1^{a}$ (goethite model; total site density $=0.066 \mathrm{~mol} / \mathrm{mol} \mathrm{Fe}$ )
$-11.2$

7.2

$-10.37$

8.35

$-4.28$

$-4.71$

0.78

$-4.71$

$-22.79$
$-9.13$

6.51

2.90

$-5.09$

$-2.34$

$-6.14$

$-12.31$

$-17.24$

$-1.72$

$-5.67$

$-17.88$

$-21.11$

a Total site density and reaction constants from ref $16 .{ }^{b}$ Total and strong site densities and reaction constants from ref 15 and modified in ref 20. ${ }^{c}$ Total site density from ref 53 and reaction constants and strong site density were fitted (see text).

Implication to U(VI) Mobility. U(VI) immobilization by metal reducing bacteria or by in situ redox biobarriers involving sorbed or structural Fe(II) has been proposed as a remediation technology for groundwater U(VI) contamination (www.lbl.gov/NABIR). This study has shown, however, that sorbed and biogenic Fe(II) resulting from the activity of dissimilatory metal-reducing bacteria (DMRB) are not reductants for $\mathrm{U}(\mathrm{VI})$ in this particular sediment comprised of phyllosilicates and Fe(III) oxides. The adsorption and structural complexes of Fe(II) in this weathered shale saprolite do not exhibit an autocatalytic effect on U(VI) reduction (30). Direct enzymatic action by DMRB is required to accomplish $\mathrm{U}(\mathrm{VI})$ reduction and immobilization in this sediment (e.g., $54,55,56$ ), and remedial approaches should be based on such knowledge.

The uranyl ion persists in pasteurized, bioreduced sediments despite a low redox state imposed by DMRB activity. Lack of appropriate kinetic pathways apparently limit U(VI) reduction. Under these conditions, the solid-liquid distribution of $\mathrm{U}(\mathrm{VI})$ is controlled by surface complexation reactions to a complex mineral suite including various phyllosilicates and crystalline Fe(III) oxides dominated by goethite. We unexpectedly found that the bioreduction of $\sim 50 \%$ of the Fe(III) oxide fraction or its reoxidation had no discernible impact on U(VI) adsorption. Absent were apparent competitive effects of sorbed Fe(II) or potential change of site concentration or affinity. This finding leads us to conclude that a single set of adsorption parameters (e.g., site concentration and surface complexation constants) may be appropriate to describe $\mathrm{U}(\mathrm{VI})$ solid-liquid distribution in these materials even during a complex remedial action involving biostimulation with later reoxidation. Moreover, a ferrihydrite-based surface complexation model provided reasonably good estimates of $\mathrm{U}(\mathrm{VI})$ sorption without parameter adjustment, while a two-site GC model provided the best simulations of $U(V I)$ adsorption and the effects of various experimental parameters when appropriately calibrated.

\section{Acknowledgments}

This research was supported by the U.S. Department of Energy (DOE) through the Natural and Accelerated Biological Remediation (NABIR) program. Pacific Northwest National Laboratory is operated for the DOE by Battelle Memorial Institute under Contract DE-AC06-76RLO 1830. We appreciate three reviewers and associated editor for their constructive comments and suggestions.

\section{Supporting Information Available}

Additional table and figures. This material is available free of charge via the Internet at http://pubs.acs.org.

\section{Literature Cited}

(1) Landa, E. R.; Gray, J. R. US Geological Survey research on the environment fate of uranium mining and milling wastes. Environ. Geol. 1995, 26, 19-31.

(2) Riley, R. G.; Zachara, J. M. Chemical contaminants on DOE lands and election of contaminant mixtures for subsurface science research; U.S. Department of Energy, Office of Energy Research: Washington, DC, 1992.

(3) Hsi, C.-K.; Langmuir, D. Adsorption of uranyl onto ferric oxyhydroxides: Application of the surface complexation sitebiding model. Geochim. Cosmochim. Acta 1985, 49, 1931-1941.

(4) Hudson, E. A.; Terminello, L. J.; Viani, B. E.; Denecke, M.; Reich, T.; Allen, P. G.; Bucher, J. J.; Shuh, D. K.; Edelstein, N. M. The structure of $\mathrm{U}^{6+}$ sorption complexes on vermiculite and hydrobiotite. Clays Clay Miner. 1999, 47, 439-457.

(5) Sylwester, E. R.; Hudson, E. A.; Allen, P. G. The structure of uranium(VI) sorption complexes on silica, alumina, and montmorillonite. Geochim. Cosmochim. Acta 2000, 64, 2431-2438.

(6) Duff, M. C.; Amrhein, C. Uranium(VI) adsorption on goethite and soil in carbonate solutions. Soil Sci. Soc. Am. J. 1996, 60, 1393-1400.

(7) Bargar, J. R.; Reimeyer, R.; Davis, J. A. Spectroscopic confirmation of uranium(VI)-carbonato adsorption complexes on hematite. Environ. Sci. Technol. 1999, 33, 2481-2484.

(8) Lenhart, J. J.; Honeyman, B. D. Uranium(VI) sorption to hematite in the presence of humic acid. Geochim. Cosmochim. Acta 1999, $63,2891-2901$.

VOL. 39, NO. 11, 2005 / ENVIRONMENTAL SCIENCE \& TECHNOLOGY $\mathbf{4 1 3 1}$ 
(9) Bargar, J. R.; Reimeyer, R.; Lenhart, J. J.; Davis, J. A. Characterization of U(VI)-carbonato ternary complexes on hematite: EXAFS and electrophoretic mobility measurements. Geochim. Cosmochim. Acta 2000, 64, 2737-2749.

(10) McKinley, J. P.; Zachara, J. M.; Smith, S. C.; Turner, G. The influence of uranyl hydrolysis and multiple site-binding reactions on adsorption of U(VI) to montmorillonite. Clays Clay Miner. 1995, 43, 586-598.

(11) Turner, G. D.; Zachara, J. M.; McKinley, J. P.; Smith, S. C. Surfacecharge properties and $\mathrm{UO}_{2}{ }^{2+}$ adsorption of a subsurface smectite. Geochim. Cosmochim. Acta 1996, 60, 3399-3414.

(12) Zachara, J. M.; McKinley, J. P. Influence of hydrolysis on the sorption of metal cations by smectites: Importance of edge coordination reactions. Aquat. Sci. 1993, 55, 250-261.

(13) Thompson, H. A.; Parks, G. A.; Brown, G. E. In Adsorption of Metals by Geomedia, Variables, Mechanisms, and Model Applications; Jenne, E. A., Ed.; Academic Press: New York, 1998; pp 349-370.

(14) Davis, J. A.; Payne, T. E.; Waite, T. D. Simulating the $\mathrm{pH}$ and $\mathrm{pCO}_{2}$ dependence of uranium(VI) adsorption by a weathered schist with surface complexation models. Geochem. Soil Radionuclides: SSSA Spec. Publ. 2002, 59, 61-86.

(15) Waite, T. D.; Davis, J. A.; Payne, T. E.; Waychunas, G. A.; Xu, N. Uranium(VI) adsorption to ferrihydrite: Application of a surface complexation model. Geochim. Cosmochim. Acta 1994, 58, 5465-5478.

(16) Villalobos, M.; Trotz, M. A.; Leckie, J. O. Surface Complexation Modeling of Carbonate Effects on the Adsorption of $\mathrm{Cr}(\mathrm{IV}), \mathrm{Pb}-$ (II), and U(VI) on Goethite. Environ. Sci. Technol. 2001, 35, 38493856 .

(17) Wazne, M.; Korfiatis, G.; Meng, X. Carbonate effects on hexavalent uranium adsorption by iron oxyhydroxide. Environ. Sci. Technol. 2003, 37, 3619-3624.

(18) Waite, T. D.; Davis, J. A.; Fenton, B. R.; Payne, T. E. Approaches to modeling uranium(VI) adsorption on natural mineral assemblages. Radiochim. Acta 2000, 88, 687-693.

(19) Barnett, M. O.; Jardine, P. M.; Brooks, S. C. U(VI) adsorption to heterogeneous subsurface media: application of a surface complexation model. Environ. Sci. Technol. 2002, 36, 937-942.

(20) Davis, J. A. Surface complexation modeling of uranium(VI) adsorption on natural mineral assemblages; U.S. Geological Survey, NUREG/CR-6708, US Nuclear Regulatory Commission: Washington, DC, 2001.

(21) Kohler, M.; Curtis, D. P.; Meece, D. E.; Davis, J. A. Methods for estimating adsorbed uranium(VI) and distribution coefficients of contaminated sediments. Environ. Sci. Technol. 2004, 38, $240-247$

(22) Lovley, D. R.; Phillips, E. J. P.; Gorby, Y. A.; Landa, E. R. Biological reduction of uranium. Nature 1991, 350, 413-416.

(23) Fredrickson, J. K.; Zachara, J. M.; Kennedy, D. W.; Duff, M. C.; Gorby, Y. A.; Li, S.-M.; Krupka, K. M. Reduction of U(VI) in goethite $(\alpha-\mathrm{FeOOH})$ suspensions by a dissimilatory metalreducing bacterium. Geochim. Cosmochim. Acta 2000, 64, 30853098.

(24) Lovley, D. R. Dissimilatory Fe(III) and Mn(IV) reduction. Microbiol. Rev. 1991, 55, 259-287.

(25) Zachara, J. M.; Fredrickson, J. K.; Li, S.-M.; Kennedy, D. W.; Smith, S. C. Bacterial reduction of crystalline Fe(III) oxides in single phase suspensions and subsurface materials. Am. Mineral. 1998, 83, 1426-1443.

(26) Myers, C. R.; Nealson, K. H. Bacterial manganese reduction and growth with manganese oxide as the sole electron acceptor. Science 1988, 240, 1319-1321.

(27) Fredrickson, J. K.; Zachara, J. M.; Kennedy, D. W.; Liu, C.; Duff, M. C.; Hunter, D. B.; Dohnalkova, A. Influence of Mn oxides on the reduction of uranium(VI) by the metal-reducing bacterium Shewanella putrefaciens. Geochim. Cosmochim. Acta 2002, 66, 3247-3262.

(28) Wielinga, B.; Mizuba, M. M.; Hansel, C. M.; Fendorf, S. Iron promoted reduction of chromate by dissimilatory iron-reducing bacteria. Environ. Sci. Technol. 2001, 35, 522-527.

(29) Fredrickson, J. K.; Zachara, J. M.; Kennedy, D. W.; McKinley, J. P.; Kukkadapu, R. K.; Liu, C.; Plymale, A. E.; Smith, S. C. Reduction of $\mathrm{TcO}_{4}^{-}$by Sediment-Associated Biogenic Fe(II). Geochim. Cosmochim. Acta 2004, 68, 3171-3187.

(30) Liger, E.; Charlet, L.; van Cappellen, P. Surface catalysis of uranium(VI) reduction by iron(II). Geochim. Cosmochim. Acta 1999, 63, 2939-2955.

(31) Missana, T.; Maffiotte, C.; Garc ía-Gutiérrez, M. Surface reactions kinetics between nanocrystalline magnetite and uranyl. J. Colloid Interface Sci. 2003, 261, 154-160.
(32) Wersin, P.; Hochella, M. F. J.; Persson, P.; Redden, G.; Leckie, J. O.; Harris, D. W. Interaction between aqueous U(VI) and sulfide minerals: Spectroscopic evidence for sorption and reduction. Geochim. Cosmochim. Acta 1994, 58, 2829-2843.

(33) Liu, C.; Zachara, J. M.; Fredrickson, J. K.; Kennedy, D. W.; Dohnalkova, A. Modeling the inhibition of the bacterial reduction of U(VI) by $\beta-\mathrm{MnO}_{2(\mathrm{~s})}$. Environ. Sci. Technol. 2002, 36, 14521459 .

(34) Schwertmann, U. The differentiation of iron oxides in soil by extraction with ammonium oxalate solution. Z. Pflanzenernaehr. Bodenkd. 1964, 105, 194-202.

(35) Fey, M. V.; LeRoux, J. Properties and quantitative estimation of poorly crystalline components in sesquioxide soil clays. Clays Clay Miner. 1977, 25, 285-294.

(36) Mehra, O. P.; Jackson, M. L. Fe Oxide removal from soils and clays by a dithionite-citrate system buffered with sodium bicarbonate. Clays Clay Miner. 1960, 7, 317-327.

(37) Fredrickson, J. K.; Zachara, J. M.; Kennedy, D. V.; Dong, H.; Onstott, T. C.; Hinman, N. W.; Li, S.-m. Biogenic iron mineralization accompanying the dissimilatory reduction of hydrous ferric oxide by a groundwater bacterium. Geochim. Cosmochim. Acta 1998, 62, 3239-3257.

(38) Sowder, A. G.; Clark, S. B.; Fjeld, R. A. The effect of sample matrix quenching on the measurement of trace uranium concentrations in aqueous solutions using kinetic phosphorimetry. J. Radioanal. Nucl. Chem. 1998, 234, 257-260.

(39) Stookey, L. L. Ferrozine - A New Spectrophotometric Reagent for Iron. Anal. Chem. 1970, 42, 779-781.

(40) Herbelin, A. L.; Westall, J. C. FITEQL, A computer program for determination of chemical equilibrium constants from experimental data, version 4.0; Department of Chemistry, Oregon State University, Corvallis, OR, 1999.

(41) Sulzberger, B.; Suter, D.; Siffert, C.; Banwart, S.; Stumm, W. Dissolution of Fe(III) (hydro) oxides in natural waters; Laboratory assessment on the kinetics controlled by surface coordination. Mar. Chem. 1989, 28, 127-144.

(42) Zachara, J. M.; Smith, S. C.; McKinley, J. P.; Resch, C. T. Cadmium sorption on specimen and soil smectites in sodium and calcium electrolytes. Soil Sci. Soc. Am. J. 1993, 57, 1491-1501.

(43) Duff, M. C.; Coughlin, J. U.; Hunter, D. B. Uranium coprecipitation with iron oxide minerals. Geochim. Cosmochim. Acta 2002, 66, 3533-3547.

(44) Duff, M. C.; Mason, C. F. V.; Hunter, D. B. Comparison of acid and base leach for the removal of uranium from contaminated soil and catch box media. Can. J. Soil Sci. 1998, 78, 675-683.

(45) Duff, M. C.; Morris, D. E.; Hunter, D. B.; Bertsch, P. M Spectroscopic characterization of uranium in evaporation basin sediments. Geochim. Cosmochim. Acta 2000, 64, 1535-1550.

(46) Mason, C. F.; Turney, W. R.; Thomson, B. M.; Lu, N.; Longmire, P. A.; Chisholm-Brause, C. J. Carbonate leaching of uranium from contaminated soils. Environ. Sci. Technol. 1997, 31, 27072711.

(47) Buck, E. C.; Brown, N. R.; Dietz, N. L. Contaminant uranium phases and leaching at the Fernald site in Ohio. Environ. Sci. Technol. 1996, 30, 81-88.

(48) Allison, J. D.; Brown, D. S.; Novo-Gradac, K. J. MINTEQA2// PRODEFA2, A geochemical assessment model for environmental systems, version 4; Environmental Research Laboratory, U.S. EPA: Athens, GA, 1998.

(49) Guillaumount, R.; Fanghänet, T.; Neck, V.; Fuger, J.; Palmer, D. A.; Grenthe, I.; Rand, M. H. Update on the Chemical Thermodynamics of Uranium, Neptunium, Plutonium, Americium and Technetium; Elsevier B. V.: Amsterdam, 2003.

(50) Nevin, K. P.; Lovley, D. R. Potential for nonenzymatic reduction of Fe(III) by electron shuttling in subsurface sediments. Environ. Sci. Technol. 2000, 34, 2472-2478.

(51) Finneran, K. T.; M. E., H.; Lovley, D. R. Multiple influences of nitrate on uranium solubility during bioremediation of uraniumcontaminated subsurface sediments. Environ. Microbiol. 2002, $4,510-516$.

(52) Istok, J. D.; Senko, J. M.; Krumholz, L. R.; Watson, D.; Bogle, M. A.; Peacock, A.; Change, Y.-J.; White, D. C. In situ bioreduction of technetium and uranium in a nitrate-contaminated aquifer. Environ. Sci. Technol. 2004, 38, 468-475.

(53) Davis, J. A.; Kent, D. B. In Mineral-Water Interface Geochemistry, Reviews in Mineralogy; Hochella, M. F., White, A. F., Eds.; Mineralogical Society of America: Washington, DC, 1990; pp 177-260.

(54) Gorby, Y. A.; Lovley, D. R. Enzymatic uranium precipitation. Environ. Sci. Technol. 1992, 26, 205-207. 
(55) Lovley, D. R.; Phillips, E. J. P. Bioremediation of uranium contamination with enzymatic uranium reduction. Environ. Sci. Technol. 1992, 26, 2228-2234.

(56) Senko, J. M.; Istok, J. D.; Suflita, J. M.; Krumholz, L. R. In-situ evidence for uranium immobilization and remediation. Environ. Sci. Technol. 2002, 36, 1491-1496.

(57) Zachara, J. M.; Smith, S. C.; Liu, C.; McKinley, J. P.; Serne, R. J.; Gassman, P. L. Sorption of $\mathrm{Cs}^{+}$to Micaceous Subsurface Sediments from the Hanford Site, USA. Geochim. Cosmochim. Acta 2002, 66, 193-211.
(58) Kalmykov, S. N.; Choppin, G. R. Mixed $\mathrm{Ca}^{2+} / \mathrm{UO}_{2}{ }^{2+} / \mathrm{CO}_{3}{ }^{2-}$ complex formation at different ionic strengths. Radiochim. Acta 2000, 88, 603-606.

Received for review September 23, 2004. Revised manuscript received March 14, 2005. Accepted March 17, 2005.

ES048501Y 